\title{
Using bivalves as particle collectors with PCR detection to investigate the environmental distribution of Haplosporidium nelsoni
}

\author{
Susan E. Ford ${ }^{1, *}$, Bassem Allam ${ }^{1,2}$, Zhe $\mathrm{Xu}^{1}$ \\ ${ }^{1}$ Haskin Shellfish Research Laboratory, Rutgers University, 6959 Miller Avenue, Port Norris, New Jersey 08349, USA \\ ${ }^{2}$ Present address: School of Marine and Atmospheric Sciences, Stony Brook University, Stony Brook, \\ New York 11794-5000, USA
}

\begin{abstract}
Recently, PCR technology has been applied to search for marine microorganisms in environmental samples. Such sampling, however, has drawbacks, including the need to collect and filter large volumes of water, and the presence of substances in environmental samples that may destroy DNA or interfere with DNA isolation and amplification. We explored the possibility of using suspension-feeding bivalves in conjunction with PCR to investigate the environmental distribution of microparasites using the oyster pathogen Haplosporidium nelsoni (the MSX disease agent) with oysters and mussels in Delaware Bay, USA, as a model system. Delaware Bay oysters Crassostrea virginica have become very resistant to $H$. nelsoni infection development and rarely exhibit histologically detectable lesions. The ribbed mussel Geukensia demissa is also resistant. Infections were detected in only $6 \%$ of the histologically examined oysters in the present study, although PCR-positive signals for $H$. nelsoni were found in feces, gill or heart samples of up to $100 \%$ of oysters. Positive signals were found in the feces and gill (but not heart) samples of up to $50 \%$ of mussels. The temporal evolution of PCR signals suggested a wave-like pattern of putative infective particles, which mimicked a pattern documented in early mortality studies. The present study demonstrated that $H$. nelsoni persists throughout Delaware Bay, although it is rarely detected using standard histology. We propose that the use of suspension-feeding bivalves as particle collectors in combination with PCR could be a method for detecting the presence of marine microparasites and might help answer questions about factors that prevent outbreaks of epizootics in certain regions.
\end{abstract}

KEY WORDS: Detection methods $\cdot$ Histology $\cdot$ Resistance $\cdot$ Parasite distribution $\cdot$ MSX $\cdot$ Epizootic $\cdot$ Marine

Resale or republication not permitted without written consent of the publisher

\section{INTRODUCTION}

The presence of a marine parasite is typically determined by examining its known host(s) for infections by traditional histological or culture methods, or, with increasing frequency, by molecular methods. Recently, PCR technology has been applied to the search for microorganisms in environmental samples, including water, sediment and on organic surfaces (Vigneron et al. 2004, Lyons et al. 2005, Audemard et al. 2006, Blackstone et al. 2007). Such sampling, however, has certain drawbacks, including the need to collect and filter large volumes of water in order to obtain sufficient material for reliable detection, and the presence of substances in environmental samples that may destroy DNA or otherwise interfere with DNA isolation and amplification (Wilson 1997, Guy et al. 2003, Audemard et al. 2004, 2006).

Suspension-feeding bivalves filter material from large volumes of water and could be considered as collectors for water-borne particles. Loosanoff \& Nomejko (1946) and Galtsoff (1964), for instance, estimated that large (100 to $120 \mathrm{~mm}$ shell height) eastern oysters Crassostrea virginica could filter up to 300 to $480 \mathrm{l} \mathrm{d}^{-1}$ (13 to 
$\left.20 \mathrm{l} \mathrm{h}^{-1}\right)$. The ability of bivalves to accumulate bacteria and viruses of concern to human health is well known (Canzonier 1988) and is also the basis for using mussels and oysters to measure water contamination (Kim \& Powell 2006). Water-borne protistan parasites of the bivalves themselves are among the particles collected by the mollusks as they filter. If the bivalve is susceptible to infection by the parasite, the gills or mantle may be among the portals of entry (Farley 1968, Chintala et al. 2002, Ford et al. 2002). If the bivalve is not susceptible, the parasites may be carried toward the mouth with other particles and discarded in the pseudofeces, or consumed and, if not destroyed by digestive enzymes, voided in the feces. Ingestion and voiding of viable dinoflagellates by suspension-feeding bivalves has been demonstrated recently (Hegaret et al. 2008). The same might also be true of parasites that are unsuccessful in infecting a susceptible host. Thus, the presence of a parasite in an area might be detected by examining the feces or pseudofeces of bivalves in that area, even if a known susceptible host is not present.

The parasite Haplosporidium nelsoni was introduced to the east coast of the United States from the Pacific, where it infects the Pacific oyster Crassostrea gigas (Burreson et al. 2000). Although H. nelsoni has not been reported to cause mortalities in that species, the eastern oyster $C$. virginica is highly susceptible and has suffered heavy losses in many regions of the eastern United States since it was first detected in Delaware Bay, USA in 1957 (Haskin et al. 1966). The life cycle and mode of transmission of $H$. nelsoni are unknown. Direct oyster-to-oyster transmission has not been demonstrated experimentally and another host has been hypothesized (Sunila et al. 1999). The earliest infections are found in the gill epithelium (Farley 1968, Ford \& Haskin 1982). Mortality ensues when infections become systemic, whereas resistance to mortality is associated with restriction of infections to the gill epithelium (Ford \& Haskin 1987). In the late 1980s, the prevalence of $H$. nelsoni in Delaware Bay oysters, as determined by traditional tissue-section histology, declined dramatically. Annual peaks of 60 to $85 \%$ in the 1970s through the mid-1980s fell to $30 \%$ or less after 1987 (Burreson \& Ford 2004). Ford (2002) hypothesized that the change resulted from a massive mortality that occurred in the mid-1980s when $H$. nelsoni moved upbay during a drought (Powell et al. 2008) leaving a bay-wide population with considerable resistance to $H$. nelsoni infection development. An alternative hypothesis is that the abundance of $H$. nelsoni has decreased, thus resulting in fewer infections.

In the present study, we used PCR technology and the concept of using suspension feeders as collectors of Haplosporidium nelsoni to investigate the parasite's temporal and spatial distribution in Delaware Bay, and to examine the potential of these tools for answering questions about the parasite that cannot be answered by traditional histological methods.

\section{MATERIALS AND METHODS}

Bivalves. Eastern oysters Crassostrea virginica were collected from several sites on the New Jersey side of Delaware Bay (Table 1, Fig. 1). Native oysters were obtained from natural beds and one leased ground

Table 1. Crassostrea virginica and Geukensia demissa. Samples analyzed for Haplosporidium nelsoni by PCR and histology. Check marks $(\checkmark)$ indicate the comparisons made or individual components examined in the samples indicated. Naïve oysters $C$. virginica originated in the Damariscotta River, Maine. Native oysters and ribbed mussels G. demissa were from Delaware Bay

\begin{tabular}{|c|c|c|c|c|c|c|c|c|c|c|}
\hline \multirow[t]{3}{*}{ Date(s) } & \multirow[t]{3}{*}{ Location } & \multirow[t]{3}{*}{ Species } & \multirow[t]{3}{*}{$\mathrm{N}$} & \multirow{3}{*}{ Feces } & \multirow{3}{*}{$\begin{array}{l}\text { Pseudo- } \\
\text { feces }\end{array}$} & \multicolumn{3}{|c|}{ PCR assay } & \multirow{3}{*}{ Heart } & \multirow{3}{*}{$\begin{array}{l}\text { Histology } \\
\text { Gill and } \\
\text { visceral } \\
\text { mass }\end{array}$} \\
\hline & & & & & & & Gill pieces & & & \\
\hline & & & & & & $\begin{array}{l}\text { Washed vs. } \\
\text { unwashed }\end{array}$ & $\begin{array}{l}\text { Adjacent } \\
\text { unwashed }\end{array}$ & $\begin{array}{c}\text { Single } \\
\text { unwashed }\end{array}$ & & \\
\hline \multicolumn{11}{|l|}{1999} \\
\hline June \& July & Cape Shore & Naïve oyster & 40 & $\checkmark$ & $\checkmark$ & $\checkmark$ & & & $\checkmark$ & \\
\hline \multirow[t]{2}{*}{ June \& August } & Maurice River & Native oyster & 21 & $\checkmark$ & & $\checkmark$ & & & $\checkmark$ & \\
\hline & Maurice River & Native mussel & 21 & $\checkmark$ & & $\checkmark$ & & & $\checkmark$ & \\
\hline $\begin{array}{l}\text { May, June, } \\
\text { July, November }\end{array}$ & $\begin{array}{l}\text { Delaware } \\
\text { Bay Beds }\end{array}$ & Native oyster & $140^{\mathrm{a}}$ & $\checkmark$ & & & $\checkmark$ & $\checkmark$ & $\checkmark$ & $\checkmark$ \\
\hline October & $554 \mathrm{D}$ & Native oyster & 20 & & & & $\checkmark$ & & $\checkmark$ & $\checkmark$ \\
\hline \multicolumn{11}{|l|}{2000} \\
\hline April, May, & Cape Shore & Native oyster & 50 & $\checkmark$ & & & & $\checkmark$ & $\checkmark$ & \\
\hline \multirow[t]{2}{*}{ June, July } & Cape Shore & Naïve oyster & 40 & $\checkmark$ & & & & $\checkmark$ & $\checkmark$ & \\
\hline & Cape Shore & Native mussel & 50 & $\checkmark$ & & & & $\checkmark$ & $\checkmark$ & \\
\hline \multirow[t]{2}{*}{ September } & Cape Shore & Native oyster & 20 & & & & & & & $\checkmark$ \\
\hline & Cape Shore & Naïve oyster & 20 & & & & & & & $\checkmark$ \\
\hline
\end{tabular}




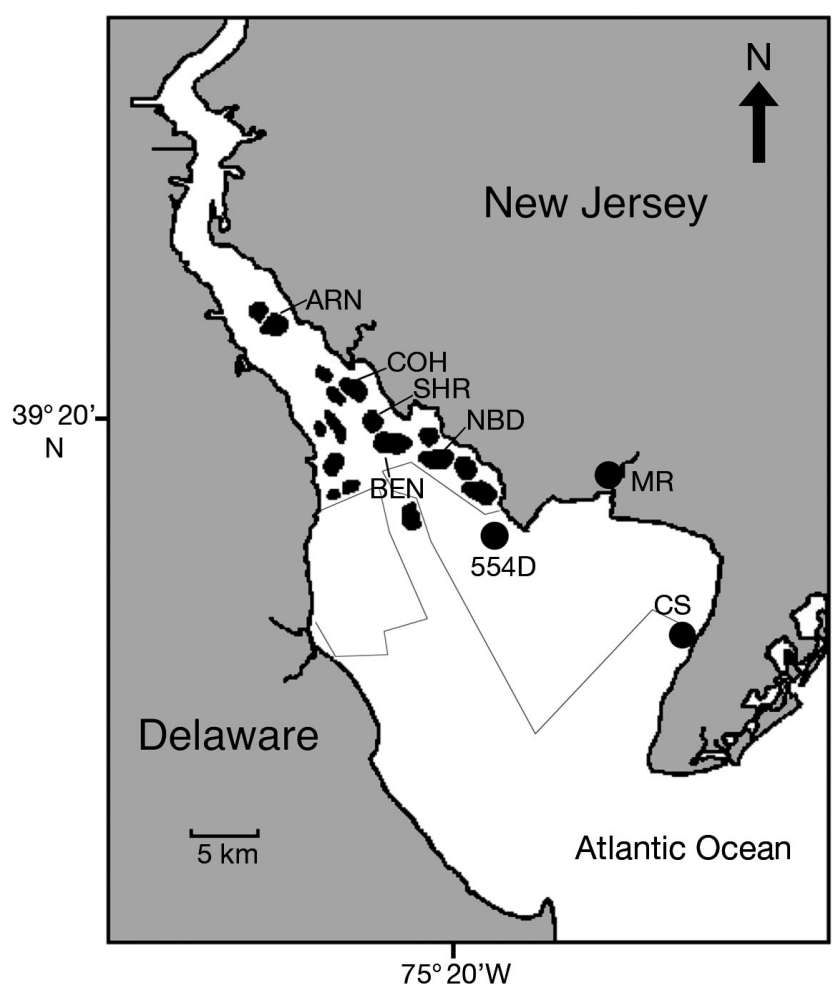

Fig. 1. Sampling locations in Delaware Bay. Upbay sites: Arnolds (ARN) and Cohansey $(\mathrm{COH})$ natural beds; mid-bay sites: Shell Rock (SHR), Bennies (BEN) and New Beds (NBD) natural beds; lower bay sites: leased ground (554D), Maurice River (MR), and Cape Shore (CS). Thin grey lines: leased grounds

from May through November 1999. Both C. virginica and the ribbed mussel Geukensia demissa were collected from the Maurice River at Bivalve in June and August 1999. At the Cape Shore intertidal flats in lower Delaware Bay, oysters were collected in June and July 1999, and both oysters and ribbed mussels were sampled from April through July 2000. Salinity at mid-tide and mean Delaware River flow ranges from about 20 to $24 \mathrm{psu}$ in the lower bay sites to $10 \mathrm{psu}$ at Arnolds Bed, the uppermost natural bed sampled. The tidal variation is typically 2 to 3 psu above and below the mean. Salinity at the Maurice River site is highly variable, ranging from 0 to 20 psu depending on tide and precipitation.

At the Cape Shore, 2 stocks of oysters were sampled: (1) 'naïve' oysters from the Damariscotta River, Maine, which have experienced little or no previous MSXdisease pressure, had no detectable Haplosporidium nelsoni infections when examined histologically at the time of importation (Haskin Shellfish Laboratory records), and are highly susceptible to infection by $H$. nelsoni; and (2) native oysters that had set on a nearby intertidal reef. The Maine oysters were held in a rack and bag system about $100 \mathrm{~m}$ from the reef. In 1999, the
Maine oysters were deployed on 27 May and the first sample was collected on 24 June. In 2000, they were deployed on 5 May and first sampled on 12 May. Mussels were collected from the same reef as the native oysters, with which they were intermingled. Although the bivalves were not measured, they were all adults, between about 60 and $80 \mathrm{~mm}$ in shell height and from 2 to $3 \mathrm{yr}$ old. Bivalve numbers ranged from 5 to 20 individuals per sample, with 2 to 5 tissue, feces and/or pseudofeces samples assayed per individual. A total of 382 individual bivalves was examined and 1108 PCR reactions were run.

Feces and pseudofeces collection. Several of the collections included sampling of feces, and one of these (Cape Shore, July 1999) also involved sampling of pseudofeces. To accomplish this, oysters and mussels were brought into the laboratory, scrubbed under running tap water and placed individually in plastic tubs containing approximately $1 \mathrm{l}$ of seawater that had been filtered through a $1 \mu \mathrm{m}$ cartridge filter. The bivalves were maintained in the tubs overnight without aeration to prevent disturbance of the feces and pseudofeces, which were collected the following morning using a Pasteur pipette and placed in separate $15 \mathrm{ml}$ centrifuge tubes. The tubes were centrifuged at 13000 to $14000 \times g$ for $2 \mathrm{~min}$ and the pellet transferred to $95 \%$ EtOH.

Tissue collection. The bivalves were carefully opened at the hinge with an oyster knife that was rinsed in tap water and then immersed in a $10 \%$ hypochlorite solution between individuals. Special care was taken not to disrupt the pericardial membrane when the adductor muscle attachment was severed. Dissecting instruments were dipped in $70 \% \mathrm{EtOH}$ and flamed between bivalves and tissues. One or 2 adjacent sections of the gill were then removed and placed in individual $1.5 \mathrm{ml}$ microfuge tubes containing $95 \% \mathrm{EtOH}$. Each section was approximately 5 to $7 \mathrm{~mm}$ long and encompassed the entire proximal to distal length of at least 2 demibranchs. Two adjacent gill pieces were assayed to help evaluate the spatial variability in PCRpositive signals on this organ. In some trials, to assess whether the DNA detected by PCR on the gill was in the tissue (implying an infection of Haplosporidium nelsoni) or enmeshed in mucus, as opposed to being loosely attached, one of the gill pieces was rinsed in a stream of $0.22 \mu \mathrm{m}$ filtered seawater before fixation. Finally, to identify systemic infections, the heart was removed and fixed in a separate tube.

PCR assay. DNA extraction was generally accomplished within 1 to $2 \mathrm{~d}$ after collection. The $95 \% \mathrm{EtOH}$ was replaced with TE buffer $(10 \mathrm{mM}$ Tris, $\mathrm{pH} 8.0$, 1.0 mM EDTA) and the tissue, feces or pseudofeces was homogenized in a $1.5 \mathrm{ml}$ microfuge tube using a sterile plastic pestle. Approximately 25 to $50 \mathrm{mg}$ of 
the homogenate was then lysed with guanidine thiocyanate (GTC) (Hill et al. 1991). The DNA was precipitated with $3 \mathrm{M}$ sodium acetate $(1: 10 \mathrm{v} / \mathrm{v}$, final concentration $176 \mathrm{mM})$ and isopropanol $(1: 6 \mathrm{v} / \mathrm{v}$, final concentration $35 \%$ ) and extracted using an ethidium bromide/high salt procedure (Stemmer 1991). At the final step, EtOH was decanted and the volume of precipitated material was roughly estimated as ranging from 'very small' $(\leq 1.5 \mu \mathrm{l})$ to 'large' ( 10 to $12 \mu \mathrm{l})$. The tube was then air dried and the resulting DNA pellet was resuspended in a volume of TE buffer that ranged from $5 \mu \mathrm{l}$ for 'very small' to $20 \mu \mathrm{l}$ for 'large' precipitate volumes. The purified DNA was stored at $4^{\circ} \mathrm{C}$ until it was amplified (usually within a week). Although DNA concentration was not measured, every effort was made to use roughly similar amounts of tissue for each sample.

A 2-stage hemi-nested PRC protocol (Zimmerman et al. 1994) was used to amplify Haplosporidium nelsoni DNA in the samples. The first stage, which employed primers MSX A and MSX B, amplified a 564 bp region of the $H$. nelsoni small subunit rDNA (SSU rDNA) (Stokes et al. 1995). The second stage, which used primers MSX A and MSX C amplified a 251 bp segment of the first region (Burreson et al. 2000). For the first amplification, $1 \mu \mathrm{l}$ of the template DNA was added to $24 \mathrm{\mu l}$ of a solution containing buffer (10 mM Tris$\mathrm{HCl}, \mathrm{pH} 8.3,50 \mathrm{mM} \mathrm{KCl}, 1.5 \mathrm{M} \mathrm{MgCl}_{2}, 10 \mu \mathrm{g} \mathrm{ml}^{-1}$ gelatin); $25 \mathrm{pmol}$ of each primer; $200 \mu \mathrm{M}$ each of dATP, dCTP, dGTP and dTTP; $10 \mu \mathrm{g}$ bovine serum albumin (BSA); and 0.6 units of AmpliTaq DNA polymerase (Perkin-Elmer). The mixtures were placed in a DeltaCycler II thermal cycler (Ericomp), denatured for $5 \mathrm{~min}$ at $94^{\circ} \mathrm{C}$, then cycled 35 times at $95^{\circ} \mathrm{C}$ for $55 \mathrm{~s}, 59^{\circ} \mathrm{C}$ for $1 \mathrm{~min}$ and $73^{\circ} \mathrm{C}$ for $3 \mathrm{~min}$, with a $5 \mathrm{~min}$ final extension at $73^{\circ} \mathrm{C}$. In the second amplification, all ingredients of the reaction mixture were the same except the buffer, which consisted of $60 \mathrm{mM}$ Tris- $\mathrm{HCl}, \mathrm{pH} 10,15 \mathrm{mM}$ $\left(\mathrm{NH}_{4}\right)_{2} \mathrm{SO}_{4}$ and $1 \mathrm{mM} \mathrm{MgCl}$. The thermal cycler program was also the same except that the annealing temperature was $53^{\circ} \mathrm{C}$ rather than $59^{\circ} \mathrm{C}$. For both amplifications, a positive control (genomic $H$. nelsoni DNA) and a negative control (water) were included. Approximately $2.5 \mathrm{\mu l}$ of each second-stage amplification product was electrophoresed on a $2 \%$ agarose gel and stained with ethidium bromide to visualize bands.

Histology. Tissue sections were made from 140 native oysters that were also processed for PCR analysis (Table 1). An additional 20 oysters each from the naïve and native groups were examined histologically after the PCR sampling at the Cape Shore was completed in 2000. All were examined and scored using previously described methods (Farley 1968, Ford \& Haskin 1982). Slides from May and July collections from the natural beds were made by sectioning the oysters frontally approximately twothirds of the distance from the distal to the proximal ends of the demibranchs and again in the same direction, but angled into the visceral mass. The 2 outside pieces were embedded cut-face down so that 2 frontal sections of the gill, as well as some of the visceral mass, were examined for each individual. All other slides were made from a single cross section that also included gill and visceral mass. The extra gill tissue of the May and July sections increased the chances of finding small, localized gill lesions during the early infection period.

\section{RESULTS}

\section{PCR assays}

Gill-sample and feces vs. pseudofeces comparisons

On a sample basis, the prevalence of PCR-positive signals on adjacent pieces of gill was comparable (Table 2). On an individual oyster basis, however, adjacent pieces did not always give the same result. That is, in the same oyster, a piece of gill with a positive signal might be adjacent to a piece with a negative result. Thus, the combined prevalence from both pieces was higher than that from only a single piece (Table 2). The greatest disparity between pieces from a single oyster was evident in samples from the uppermost bay site and the Maurice River, both relatively low-salinity sites compared to the mid-bay and Cape Shore sites. In the low-salinity sites, only 50 to $67 \%$ of the results of one piece (positive or negative) matched that of the other. In the high-salinity sites, the matches were 80 to $90 \%$. Washing had no significant effect on the results (paired sign test: $\mathrm{p}=0.250$ ) (Table 3 ). In the single 20

Table 2. Crassostrea virginica. Percent prevalence of Haplosporidium nelsoni PCR-positive signals on adjacent pieces of unwashed $C$. virginica gill. The Cape Shore sample consisted of naïve oysters; all others were natives. Dates given as $\mathrm{mm} / \mathrm{dd} / \mathrm{yy} . \mathrm{N}=$ total number of oysters sampled. Matches = percent of paired samples with the same result, positive or negative

\begin{tabular}{|c|c|c|c|c|c|c|}
\hline \multirow{2}{*}{$\begin{array}{l}\text { Sample } \\
\text { location }\end{array}$} & \multirow[t]{2}{*}{ Date } & \multirow[t]{2}{*}{$\mathrm{N}$} & \multicolumn{4}{|c|}{ — Prevalence (\%) } \\
\hline & & & Gill 1 & Gill 2 & $\begin{array}{c}\text { Combined } \\
\text { total }\end{array}$ & Matches \\
\hline Upper Beds & 07/14/99 & 10 & 80 & 70 & 100 & 50 \\
\hline Central Beds & 07/14/99 & 10 & 90 & 90 & 100 & 80 \\
\hline Cape Shore & 07/26/99 & 20 & 90 & 80 & 90 & 90 \\
\hline Maurice River & 08/24/99 & 10 & 10 & 30 & 40 & 67 \\
\hline $554 \mathrm{D}$ & $10 / 29 / 99$ & 20 & 50 & 55 & 60 & 85 \\
\hline
\end{tabular}


Table 3. Crassostrea virginica and Geukensia demissa. Percent prevalence of Haplosporidium nelsoni PCR-positive signals on adjacent pieces of washed and unwashed oyster $C$. virginica and mussel $G$. demissa gill. The Cape Shore sample consisted of naïve oysters; Maurice River oysters and mussels were natives. Dates given as $\mathrm{mm} / \mathrm{dd} / \mathrm{yy}$. $\mathrm{N}=$ total number of bivalves sampled. Matches $=$ percent of paired samples with the same result, positive or negative

\begin{tabular}{|c|c|c|c|c|c|c|c|}
\hline \multirow[t]{2}{*}{ Species } & \multirow{2}{*}{$\begin{array}{l}\text { Sample } \\
\text { location }\end{array}$} & \multirow[t]{2}{*}{ Date } & \multirow[t]{2}{*}{$\mathrm{N}$} & \multicolumn{4}{|c|}{$\longrightarrow$ Prevalence $(\%)$} \\
\hline & & & & Washed & $\begin{array}{c}\text { Un- } \\
\text { washed }\end{array}$ & $\begin{array}{c}\text { Combined } \\
\text { total }\end{array}$ & Matches \\
\hline Oyster & Cape Shore & 06/24/99 & 20 & 100 & 90 & 100 & 90 \\
\hline Oyster & Maurice River & 06/21/99 & 11 & 36 & 27 & 64 & 45 \\
\hline Mussel & Maurice River & 06/21/99 & 11 & 9 & 0 & 9 & 91 \\
\hline
\end{tabular}

just 7 d earlier, were already showing PCR prevalences equal to those of the native oysters: 70 and $90 \%$ in the feces and gill samples, respectively. Positive signals were also found in the feces $(20 \%)$ and gill (50\%) samples of ribbed mussels collected at the same time. In early June, observed prevalences were unchanged in the naïve oysters and the mussels, but had fallen to $40-50 \%$ in the native oysters. Little additional change was found in gill samples of all groups at the final 2 collection dates, 29 June and 20 July. Importantly, no oyster sample in which both were analyzed, pseudofeces had a PCR-positive prevalence of $89 \%$ and feces had a prevalence of $71 \%$. These values were not statistically different (chi-square: $\mathrm{df}=1, \mathrm{p}=0.638$ ).

\section{Spatial and temporal distribution on natural beds}

PCR-positive signals were present in the feces, gill and heart samples of oysters from each of the natural bed locations at each sampling date in 1999. Samples were grouped into upbay and mid-bay beds to (1) simplify presentation (Fig. 2), (2) because, historically, the beds within each group had similar Haplosporidium nelsoni prevalences (Haskin \& Ford 1982), and (3) because no significant differences in PCR signals were detected among the beds within each designated region (chisquare: $p$ > 0.05). Eighty to $100 \%$ of feces and gill samples from both regions were PCR-positive in the May sample, but prevalence was only $20 \%$ in heart samples. In both regions, the prevalence of signals on the gill dropped to $\leq 50 \%$ in early June (feces were not sampled then), but was again 80 to $90 \%$ by mid-July. In July, positive signals were found in the feces of half the oysters sampled on the mid-bay beds, but none was detected in feces from the upbay beds. By early November, the prevalence of gill signals had again dropped to $\leq 50 \%$. At no sample date did the prevalence of positive signals in the heart exceed $30 \%$. All oysters with PCR-positive heart samples also had PCR-positive gill samples.

\section{Oysters vs. ribbed mussels}

Sampling at the Cape Shore site in 2000 detected PCR-positive signals in the feces (40\%) and gills (80\%) of the native oysters at the first collection, on 15 April (Fig. 3). At the same time, positive signals were found in the feces and gills of $20 \%$ of the ribbed mussels collected on the same reef. A month later, in midMay, naïve (Maine) oysters, which had been deployed positive signals were detected in the feces of any of the groups in the late June sample, but they were again present in all 3 groups in the July sample, at which time they were abundant: 50 and $80 \%$ in the native and naïve oysters, respectively. Positive results in the hearts of the native oysters, which were sampled at all 4 times, never rose above $30 \%$, whereas those of the naïve group were already $60 \%$ when first sampled at the end of June and rose to $80 \%$ by 20 July. No positive signals were detected in mussel hearts, which were sampled in April and July.

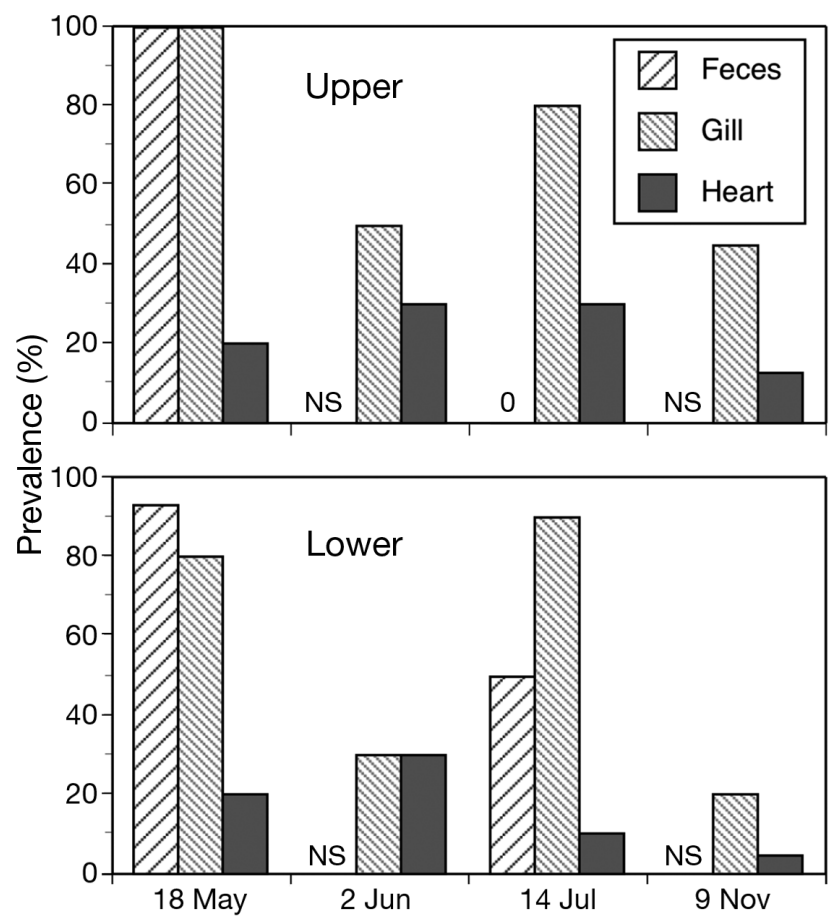

Fig. 2. Crassostrea virginica. Prevalence (\%) of Haplosporidium nelsoni PCR-positive signals in tissues and feces of native oysters C. virginica collected in 1999 from 2 regions of the natural beds of Delaware Bay. May: $\mathrm{N}=5$ oysters for upbay, 15 for mid-bay; June \& July: N = 10 for both areas; November: $\mathrm{N}=20$ for both areas. Feces and tissue samples on a given date were collected from the same individuals. NS: not sampled 


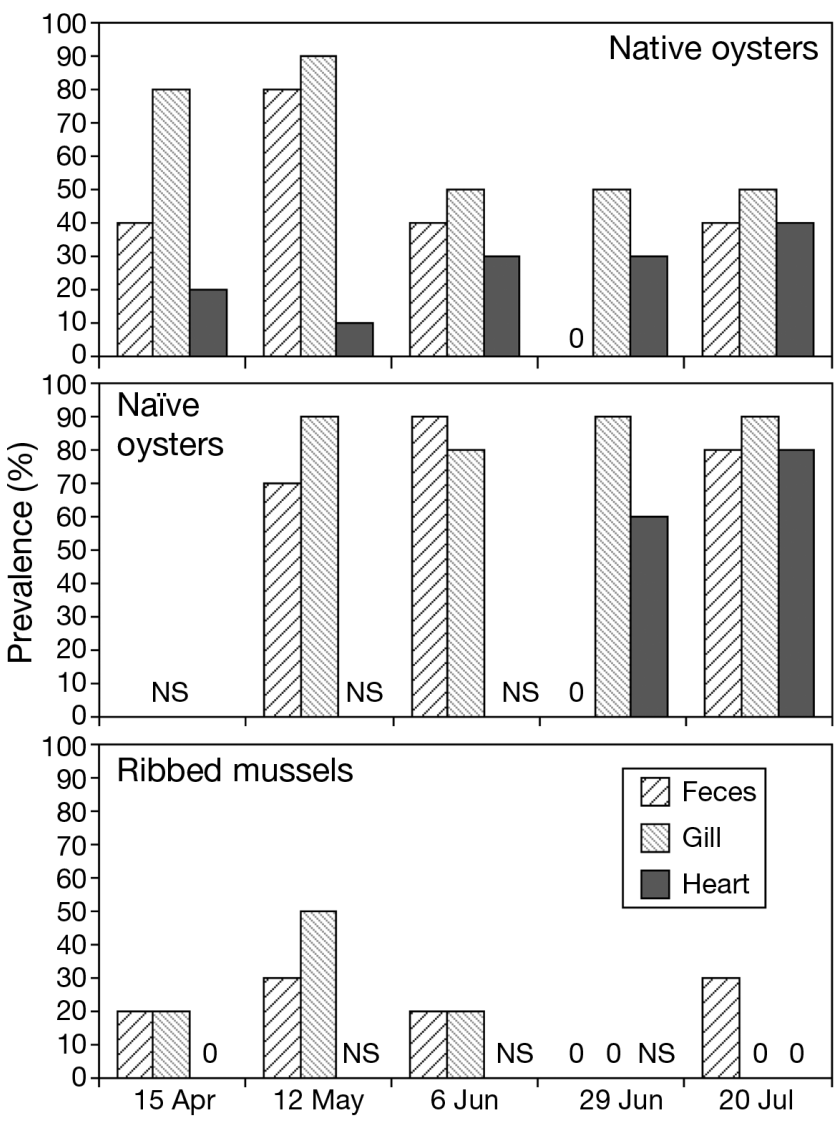

Fig. 3. Crassostrea virginica and Geukensia demissa. Prevalence (\%) of Haplosporidium nelsoni PCR-positive signals in tissues and feces of native and naïve oysters $C$. virginica and ribbed mussels G. demissa collected in 2000 at the Cape Shore in lower Delaware Bay. $\mathrm{N}=10$ bivalves at each date. Feces and tissue samples on a given date were collected from the same individuals. NS: not sampled

\section{Histology}

Of the 140 native oysters from Delaware Bay beds that were examined by both histology and PCR, only 10 (5.7\%) had Haplosporidium nelsoni that was detected by histology. Eight of these infections were localized in the gill epithelium; the other 2 were light systemic infections. All 10 oysters were positive by PCR from their gill tissue DNA and 3 were positive from heart tissue DNA. Of the remaining 130 oysters in which no histologically detected infections were found, 65 were positive using PCR on gill tissue and 15 of these were also positive in heart tissue. In early September 2000, about 5 wk after the last PCR assay, 20 each of the naïve and native oysters from the Cape Shore were examined histologically. All of the former had histologically detected infections. Half were systemic, and half of these were already very heavy. Only one native oyster was found to be infected by histology and it had a rare infection $(<10$ plasmodia in the section) localized in the gill epithelium.

\section{DISCUSSION}

Using PCR technology and oysters and mussels as particle collectors, we were able to describe some spatial and temporal patterns of the oyster pathogen Haplosporidium nelsoni in Delaware Bay that were not apparent using traditional histological methods. We inferred the parasite's distribution based on PCR-positive signals in tissues and feces. In assessing these results, it is important to stress that PCR detected a segment of DNA from a single gene, not the parasite itself. A PCR-positive signal does not necessarily indicate an infection or even a viable parasite (Burreson 2008). Further, since it is impossible to test primers against all potentially similar organisms, cross-reactions could result in false positives. Even though we found very few infections by histology in the oysters we assayed by PCR, we conclude that the PCR signals we detected represent $H$. nelsoni DNA for 3 reasons: (1) the parasite has been present in Delaware Bay for decades, (2) all oysters determined to be infected by histology were also PCR positive, and (3) the primers that we employed amplify a sequence that, to date, has been found to be unique and specific for $H$. nelsoni among the haplosporidians whose SSU rDNA has been sequenced (Bearham et al. 2007), including $H$. costale and Minchinia teredinis, which may co-occur with H. nelsoni.

From 1957, when Haplosporidium nelsoni was first associated with massive mortalities of native oysters in Delaware Bay, until 1987, fall prevalence peaks, determined by histology, were typically above $50 \%$ (Ford \& Haskin 1982, Burreson \& Ford 2004). During the decade and a half before 1988, prevalence maxima were 60 to $85 \%$. In 1988, prevalence in native oysters dropped abruptly. Since then, oysters collected during the fall survey on the Delaware Bay natural beds, as well as yearly samples of natives from the Cape Shore taken during a period from late summer into early fall since 1998, have had prevalences $\leq 30 \%$, and most samples have been histologically negative (S. E. Ford \& D. Bushek, unpubl. Haskin Shellfish Research Laboratory records). Nevertheless, results of the present study indicate that, a decade after the sharp decline in histologically detectable infections, $H$. nelsoni was still prevalent in Delaware Bay and widespread along the salinity gradient. The latter result contrasts with the clear prevalence decrease, pre-1988, of histologically detectable infections along the same gradient (Haskin \& Ford 1982) and the documented inability of $H$. nelsoni plasmodia to survive low salinity both in vivo and in vitro (Andrews 1983, Ford 1985, Ford \& Haskin 1988).

The 'presence/absence' PCR methodology used did not permit us to estimate the quantity of Haplosporid- 
ium nelsoni DNA in the individual samples, which might reflect the abundance of parasites in the water, but the prevalence of individual oysters with positive results was similar regardless of position along the gradient. Our data are consistent with another study in which Barber \& Ford (1992) reported finding ingested haplosporidian spores, matching the size and shape of $H$. nelsoni spores, in the guts of oysters throughout Delaware Bay. Thus, the decline of histologically detectable infections measured along salinity gradients in both Delaware Bay and the James River, Virginia (Andrews 1964, Haskin \& Ford 1982) may result more from a failure of $H$. nelsoni to successfully infect and proliferate in oysters at lower salinity than an absence of parasites in those waters. Because the complete life cycle of $H$. nelsoni is unknown, it may also be possible that some of the PCR-positive signals are evidence of a stage that is not infective to oysters.

Albeit limited, our attempts to wash putative Haplosporidium nelsoni from gills were not successful. Similarly, in a previous study, PCR-positive signals in seed oysters did not disappear after depuration in filtered, UV-treated water (Ford et al. 2001). At least some of these signals may well indicate parasites in very small, localized gill lesions. Others may represent parasites that are not in the tissue, but have become trapped in mucus on the gill surface. The PCR-positive signals in the mussel gill samples suggested parasites that could be trapped in mucus or even degraded parasites. Although histological sections of ribbed mussels were not examined in the present study, a previous in vitro investigation showed that $H$. nelsoni plasmodia were quickly phagocytosed by hemocytes of this species, implying that the parasite would not survive long if it did invade the mussel (Ford et al. 1993). The fact that no PCR-positive heart samples were found in mussels reinforces this argument.

Early investigations into the Haplosporidium nelsoni-caused epizootic included timed importation of naïve oysters into Delaware Bay and showed that mortality patterns depended on when the oysters were deployed and presumably when they became infected (Haskin et al. 1965). Ford \& Haskin (1982, p. 124) interpreted these data as indicating an infective period for lower Delaware Bay 'that begins and is heaviest in June, decreases in mid-summer, then resumes with varying intensity later in the summer and may extend into November'. Our molecular data also support the concept of waves of infective particles. This is shown in the feces data from the 2 sequential sampling series. In 1999, PCR signals in feces declined from $100 \%$ in midMay to $0 \%$ in mid-July on the upbay beds, and from 90 to $50 \%$ in the mid-bay samples. In the Cape Shore samples collected in 2000, all groups had positive signals (up to $90 \%$ in oysters and $30 \%$ in ribbed mussels) in May and early June, but by the end of June all feces samples were negative. Three weeks later, the feces of all groups once again showed positive signals, at prevalences up to $80 \%$ (naïve oysters). It could be argued that positive results in the feces represent parasites being shed from infected oysters rather than parasites collected from the water being voided directly in the feces or pseudofeces. In fact, in the present study, the prevalence of positive signals in feces, gill and heart was highest in the naïve oysters and lowest in the mussels, suggesting that the different sample results were not independent in all cases. However, the drop to $0 \%$ prevalence in feces occurred simultaneously in all 3 groups at the Cape Shore, despite the continued presence of positive signals in the gill and heart samples. Similarly, the $0 \%$ prevalence in feces of upper natural bed oysters was concurrent with $80 \%$ prevalence in the gill samples from the same individuals. Thus, infection - or at least the presence of parasites on the gill — does not necessarily mean that parasites are shed into the feces. We argue, therefore, that PCRpositive signals in the feces or pseudofeces can be decoupled from infections, particularly in relatively resistant bivalves with low infection levels, and certainly in non-hosts, and can serve as an index of parasite presence in the water.

The PCR prevalence of gills from oysters in the 1999 upbay series also suggested a wave-like infective pattern with prevalences of 80 to $100 \%$ in mid-May, 30 to $50 \%$ in early June, 80 to $90 \%$ in mid-July and 20 to $40 \%$ in early November. This pattern is also a demonstration of resistance to infection development in the native oysters. Before 1988, gill epithelial lesions typically progressed into systemic infections in the late summer and most infections were systemic for the remainder of the fall and winter (Ford \& Haskin 1982). This pattern was apparent in the PCR results from the naïve oysters at the Cape Shore in 2000, in which positive signals were prevalent in the heart within 2 mo of deployment. High infection prevalence was later confirmed by histology. In contrast, the pattern shown on the natural beds in the present study suggests that very light and localized gill infections (or perhaps just 'externally' adhering parasites), not detected in most histological sections examined from the same oysters, were acquired and then lost at least twice during the 1999 study period.

Our results were obtained in an estuary where Haplosporidium nelsoni has been observed in tissue sections since it was first identified in 1958; these results are consistent with mortality and ingested-spore data from earlier studies (Haskin et al. 1965, Barber \& Ford 1992). Our finding of so few histologically detectable infections in the native oysters was beneficial because it allowed us to make inferences about the presence of 
$H$. nelsoni in the environment without viewing the parasite in oysters. The question becomes whether we can draw the same inference from samples collected in regions where the parasite has never, or only rarely, been seen histologically. We should certainly be skeptical of equating PCR-positive findings with infections (Burreson 2008); however, we do know that H. nelsoni can exist in areas without causing epizootics, even though the oysters in these areas prove to be highly susceptible when tested in enzootic locations (Ford \& Haskin 1987). For instance, the parasite was detected histologically in Long Island Sound oysters in 1960 and on Cape Cod in 1967, but the first epizootics in these locations were not recorded until the mid-1980s (Haskin \& Andrews 1988, Matthiessen et al. 1990, Sunila et al. 1999). In southern Maine, H. nelsoni was detected as early as 1983 (Sherburne \& Bean 1991), but the first reported epizootic did not occur until 1995 (Barber et al. 1997). Plasmodial stages of what is presumed to be $H$. nelsoni have been reported, although at relatively low prevalence, as far south along the US east coast as Florida without causing recorded epizootics or mortality (Hillman et al. 1988, Lewis et al. 1992, Dougherty et al. 1993, Bobo et al. 1996, Kim \& Powell 2006). The recent report of high (30 of 41 oysters analyzed) $H$. nelsoni prevalence in the Gulf of Mexico, which is based on PCR results only (Ulrich et al. 2007), is intriguing because the parasite has not been detected in numerous histological surveys of eastern oysters throughout the Gulf (Winstead 1995, Winstead et al. 2004, Kim \& Powell 2006, Y. Kim pers. comm.).

What has prevented epizootic outbreaks in these areas? Is it a paucity of infective stages, an environmental factor that inhibits infection development or a combination of these or other factors? The results of the present study suggest a way of distinguishing between these alternatives for Haplosporidium nelsoni and perhaps other marine parasites. PCR can clearly detect the presence of a parasite and quantitative PCR can provide an estimate of abundance (Yarnall et al. 2000, Audemard et al. 2004). Finding few or no PCR signals would suggest that the parasite is either not present in the environment or not abundant enough to result in histologically detectable infections. In the case of $H$. nelsoni, this scenario might be associated with the absence or scarcity of a hypothesized alternate or intermediate host. Finding PCR-positive signals to be prevalent without concomitant histologically detectable infections in a susceptible host would indicate that the environment is not favorable for the development of infections or that the PCR signals are detecting a stage of the parasite that is not infective for the host in question. A logical next step would be in situ hybridization (in the host species), which often locates parasites not obvious with traditional stains (Audemard et al. 2002, Carnegie et al. 2003, Bearham et al. 2008). The presence of a parasite could even be signaled by a non-host, as demonstrated by our finding of PCR-positive reactions for $H$. nelsoni in the feces and gill samples of ribbed mussels. Detection in the feces or pseudofeces is particularly attractive because it is a non-destructive technique and can be used with both host and non-host species. Looking for parasite DNA in the feces or the gills, particularly of a host in which infections do not become established, would also be a simple and inexpensive method of identifying periods when that parasite is present in the water and potentially infective. Although our protocol does not identify possible environmental factor(s) responsible for limiting infection development, it is an expedient way to suggest the directions that research might take.

Acknowledgements. We thank G. Debrosse for providing facilities at the Rutgers Cape Shore Laboratory, R. Barber for preparing and reading histological sections and W. J. Canzonier and D. Bushek for perceptive comments on the manuscript.

\section{LITERATURE CITED}

Andrews JD (1964) Oyster mortality studies in Virginia. IV. MSX in James River public seed beds. Proc Natl Shellfish Assoc 53:65-84

Andrews JD (1983) Minchinia nelsoni (MSX) infections in the James River seed-oyster area and their expulsion in spring. Estuar Coast Shelf Sci 16:255-269

Audemard C, Le Roux F, Barnaud A, Collins C and others (2002) Needle in a haystack: involvement of the copepod Paracartia grani in the life-cycle of the oyster pathogen Marteilia refringens. Parasitology 124:315-323

Audemard C, Reece KS, Burreson EM (2004) Real-time PCR for detection and quantification of the protistan parasite Perkinsus marinus in environmental waters. Appl Environ Microbiol 70:6611-6618

> Audemard C, Calvo LMR, Paynter KT, Reece KS, Burreson EM (2006) Real-time PCR investigation of parasite ecology: in situ determination of oyster parasite Perkinsus marinus transmission dynamics in lower Chesapeake Bay. Parasitology 132:827-842

Barber RD, Ford SE (1992) Occurrence and significance of ingested haplosporidan spores in the eastern oyster, Crassostrea virginica (Gmelin, 1791). J Shellfish Res 11: 371-375

Barber BJ, Langan R, Howell TL (1997) Haplosporidium nelsoni (MSX) epizootic in the Piscataqua river estuary (Maine/New Hampshire, USA). J Parasitol 83:148-150

Bearham D, Spiers Z, Raidal S, Jones JB, Nicholls PK (2007) Molecular characterisation of a haplosporidian parasite infecting rock oysters Saccostrea cuccullata in north Western Australia. J Invertebr Pathol 95:33-40

> Bearham D, Spiers Z, Raidal S, Jones JB, Nicholls PK (2008) Detection of Minchinia sp., in rock oysters Saccostrea cuccullata (Born, 1778) using DNA probes. J Invertebr Pathol 97:50-60 
Blackstone GM, Nordstrom JL, Bowen MD, Meyer RF, Imbro P, DePaola A (2007) Use of a real time PCR assay for detection of the ctxA gene of Vibrio cholerae in an environmental survey of Mobile Bay. J Microbiol Methods 68:254-259

Bobo MY, Richardson D, Cheng TC, McGovern E, Coen L (1996) Seasonal cycle of Haplosporidium nelsoni (MSX) in intertidal oysters, Crassostrea virginica, in South Carolina. J Shellfish Res 15:525

Burreson EM (2008) Misuse of PCR assay for diagnosis of mollusc protistan infections. Dis Aquat Org 80:81-83

Burreson EM, Ford SE (2004) A review of recent information on the Haplosporidia, with special reference to Haplosporidium nelsoni (MSX disease). Aquat Living Resour 17:499-517

Burreson EM, Stokes NA, Friedman CS (2000) Increased virulence in an introduced pathogen: Haplosporidium nelsoni (MSX) in the eastern oyster Crassostrea virginica. J Aquat Anim Health 12:1-8

Canzonier W (1988) Public health component of bivalve shellfish production and marketing. J Shellfish Res 7:261-266

> Carnegie RB, Barber BJ, Distel DL (2003) Detection of the oyster parasite Bonamia ostreae by fluorescent in situ hybridization. Dis Aquat Org 55:247-252

Chintala MM, Bushek D, Ford SE (2002) Comparison of in vitro-cultured and wild-type Perkinsus marinus. II. Dosing methods and host response. Dis Aquat Org 51:203-216

Dougherty WJ, Cheng TC, Burrell VG Jr (1993) Occurrence of the pathogen Haplosporidium nelsoni in oysters, Crassostrea virginica, in South Carolina. Trans Am Microsc Soc 112:75-77

Farley CA (1968) Minchinia nelsoni (Haplosporida) disease syndrome in the American oyster Crassostrea virginica. J Protozool 15:585-599

Ford SE (1985) Effects of salinity on survival of the MSX parasite Haplosporidium nelsoni (Haskin, Stauber, and Mackin) in oysters. J Shellfish Res 2:85-90

Ford SE (2002) Development of high disease resistance in a wild oyster population. J Shellfish Res 21:387

$>$ Ford SE, Haskin HH (1982) History and epizootiology of Haplosporidium nelsoni (MSX), an oyster pathogen, in Delaware Bay, 1957-1980. J Invertebr Pathol 40:118-141

Ford SE, Haskin HH (1987) Infection and mortality patterns in strains of oysters Crassostrea virginica selected for resistance to the parasite Haplosporidium nelsoni (MSX). J Parasitol 73:368-376

Ford SE, Haskin HH (1988) Comparison of in vitro salinity tolerance of the oyster parasite Haplosporidium nelsoni (MSX) and hemocytes from the host, Crassostrea virginica. Comp Biochem Physiol A 90:183-187

Ford SE, Kanaley SA, Ashton-Alcox KA (1993) In vitro interactions between bivalve hemocytes and the oyster pathogen Haplosporidium nelsoni (MSX). J Parasitol 79: 255-265

Ford SE, Xu Z, DeBrosse G (2001) Use of particle filtration and UV irradiation to prevent infection by Haplosporidium nelsoni (MSX) and Perkinsus marinus (Dermo) in hatchery-reared larval and juvenile oysters. Aquaculture 194:37-49

Ford SE, Kraeuter JN, Barber RD, Mathis G (2002) Aquaculture-associated factors in QPX disease of hard clams: density and seed source. Aquaculture 208:23-38

Galtsoff PS (1964) The American oyster, Crassostrea virginica Gmelin, Vol 64. United States Department of the Interior, Washington, DC

Guy RA, Payment P, Krull UJ, Horgen PA (2003) Real-time PCR for quantification of Giardia and Cryptosporidium in environmental water samples and sewage. Appl Environ
Microbiol 69:5178-5185

Haskin HH, Andrews JD (1988) Uncertainties and speculations about the life cycle of the eastern oyster pathogen Haplosporidium nelsoni (MSX). In: Fisher WS (ed) Disease processes in marine bivalve molluscs, Vol 18. American Fisheries Society, Bethesda, MD, p 5-22

> Haskin HH, Ford SE (1982) Haplosporidium nelsoni (MSX) on Delaware Bay seed oyster beds: a host-parasite relationship along a salinity gradient. J Invertebr Pathol 40: 388-405

Haskin HH, Canzonier WJ, Myhre JL (1965) The history of MSX on Delaware Bay oyster grounds, 1957-65. Am Malacol Union Annu Rep 32:20-21

> Haskin HH, Stauber LA, Mackin JA (1966) Minchinia nelsoni n. sp. (Haplosporida, Haplosporidiidae): causative agent of the Delaware Bay oyster epizootic. Science 153: $1414-1416$

> Hégaret H, Shumway SE, Wikfors GH, Pate S, Burkholder JM (2008) Potential transport of harmful algae via relocation of bivalve molluscs. Mar Ecol Prog Ser 361:169-179

Hill WE, Keasler SP, Trucksess MW, Feng P, Kaysner CA, Lampel KA (1991) Polymerase chain reaction identification of Vibrio vulnificus in artificially contaminated oysters. Appl Environ Microbiol 57:707-711

Hillman RE, Boehm PD, Freitas SY (1988) A pathology potpourri from the NOAA mussel watch program. J Shellfish Res 7:216

Kim Y, Powell EN (2006) Relationships among parasites and pathologies in sentinel bivalves: NOAA status and trends 'Mussel Watch' program. Bull Mar Sci 79:83-112

Lewis EJ, Kern FG, Rosenfield A, Stevens SA, Walker RL, Heffernan PB (1992) Lethal parasites in oysters from coastal Georgia, with discussion of disease and management implications. Mar Fish Rev 52:1-6

Loosanoff VL, Nomejko CA (1946) Feeding of oysters in relation to tidal stages and to periods of light and darkness. Biol Bull (Woods Hole) 90:244-264

Lyons MM, Ward JE, Smolowitz R, Uhlinger KR, Gast RJ (2005) Lethal marine snow: pathogen of bivalve mollusc concealed in marine aggregates. Limnol Oceanogr 50: 1983-1988

Matthiessen GC, Feng SY, Leibovitz L (1990) Patterns of MSX (Haplosporidium nelsoni) infection and subsequent mortality in resistant and susceptible strains of the eastern oyster Crassostrea virginica (Gmelin, 1791) in New England. J Shellfish Res 9:359-366

Powell EN, Ashton-Alcox KA, Kraeuter JN, Ford SE, Bushek D (2008) Long-term trends in oyster population dynamics in Delaware Bay: regime shifts and response to disease. J Shellfish Res 27:729-755

Sherburne SW, Bean LL (1991) Final progress report on the pathological testing program to detemine the nature and extent of the MSX (Haplosporidium nelsoni) disease problem in Damariscotta River American oysters, Crassostrea virginica. Maine Department of Natural Resources, West Boothbay, ME

Stemmer W (1991) A 20-minute ethidium bromide/high-salt extraction protocol for plasmid DNA. Biotechniques 10:726

Stokes NA, Siddall ME, Burreson EM (1995) Detection of Haplosporidium nelsoni (Haplosporidia, Haplosporidiidae) in oysters by PCR amplification. Dis Aquat Org 23: $145-152$

Sunila I, Karolus J, Volk J (1999) A new epizootic of Haplosporidium nelsoni (MSX), a haplosporidian oyster parasite, in Long Island Sound, Connecticut. J Shellfish Res 18:169-174 
Ulrich PN, Colton CM, Hoover CA, Gaffney PM, Marsh AG (2007) Haplosporidium nelsoni (MSX) rDNA detected in oysters from the Gulf of Mexico and the Caribbean Sea. J Shellfish Res 26:195-199

Vigneron V, Solliec G, Montanié H, Renault T (2004) Detection of Ostreid Herpesvirus 1 (OsHV-1) DNA in seawater by PCR: influence of water parameters in bioassays. Dis Aquat Org 62:35-44

Wilson IG (1997) Inhibition and facilitation of nucleic acid amplification. Appl Environ Microbiol 63:3741-3751

Winstead JT (1995) Digestive tubule atrophy in eastern oysters, Crassotrea virginica (Gmelin, 1791), exposed to

Editorial responsibility: Eugene Burreson,

Gloucester Point, Virginia, USA salinity and starvation stress. J Shellfish Res 14:105-111

Winstead JT, Volety AK, Tolley SG (2004) Parasitic and symbiotic fauna in oysters (Crassostrea virginica) collected from the Caloosahatchee River and Estuary in Florida. J Shellfish Res 23:831-840

Yarnall HA, Reece KS, Stokes NA, Burreson EM (2000) A quantitative competitive polymerase chain reaction assay for the oyster pathogen Perkinsus marinus. J Parasitol 86:827-837

Zimmerman K, Pischinger K, Mannhalter JW (1994) Nested primer PCR detection limits of HIV-1 in the background of increased numbers of lysed cells. Biotechniques 17:18-20

Submitted: October 2, 2008; Accepted: December 5, 2008 Proofs received from author(s): February 2, 2009 